\title{
Uşak ilinde arı ürünlerinin tüketim durumları
}

\section{Statues of bee products consumption in Uşak Province}

\author{
Nuray ŞAHINLER ${ }^{1 \mathscr{D}}$ (D), Selçuk ÇETINKAYA ${ }^{2}$ iD, Nesibe Özge TOY ${ }^{2}$ iD \\ ${ }^{1}$ Uşak Unıversıty Agriculture Faculty/Animal Science Department/Uşak/Turkey. \\ ${ }^{2}$ Uşak Unıversıty Graduate Education Institute/Zootechnıa / Uşak/Turkey.
}

MAKALE BILGISI / ARTICLE INFO

\section{Makale tarihçesi / Article history:}

DOI: $10.37908 /$ mkutbd.824699

Geliş tarihi /Received:11.11.2020

Kabul tarihi/Accepted:27.11.2020

\section{Keywords:}

Usak province, bee products, questionnaire, consumption.

\footnotetext{
Corresponding author: Nuray ŞAHINLER

$\varangle$ :nuray.sahinler@usak.edu.tr
}

\section{ÖZET / ABSTRACT}

Aims: To determine the consumer characteristics, habits and awareness of bee products in Uşak province, which is located in the Aegean Region, and to evaluate the awareness of bee products

Methods and Results: The material of the study was composed of original data as a result of the questionnaire study, which was conducted on 80 people over 20 academicians, 20 civil servants, 20 people selected from outside the university and 20 students randomly selected from the city of Uşak. The education level of $50 \%$ of the consumers participating in the study is university; It has been determined that $50 \%$ of them have an income of 3000 TL and above, $99 \%$ of them consume bee products. It has been determined that honey is the most consumed bee product among the bee products. While $74 \%$ of consumers buy bee products, packaged, branded products are preferred. As a result, it was stated that the awareness of bee products increased according to the education level and increasing income level.

Conclusions: Our country, with its rich plant flora and variety of herbal products, allows beekeepers to obtain various honey (secretion and flower honey) and beekeeping products with different nutrient content by changing a few places throughout the year, not depending on any location and region. As a result of beekeeping activities, many products such as beeswax, royal jelly, pollen, bee venom and propolis are obtained in addition to honey, queen bee and swarm production. As a result of the study, it was observed that the majority of the participants have information about bee products and consume them. However, it was determined that the promotion of bee products was insufficient and the necessary institutions should carry out a more effective promotion work.

Significance and Impact of the Study: With this study, the tendencies of consumers to bee products in the province of Uşak, located in the Aegean Region, were determined. At the same time, it is thought that consumption preferences, places to buy bee products, deficiencies in the sale of bee products will be determined and will constitute a source for beekeepers and other studies to be done.

Atıf / Citation: Çimrin KM, Yalçın M, Keleş N (2021) Gaziantep ili Nizip ilçesi zeytin bahçeleri topraklarının bor durumunun belirlenmesi. MKU. Tar. Bil. Derg. 26(1) : 155-162. DOI: 10.37908/mkutbd.824699

\section{GiRiş}

Arıcılık; kaynağını direkt doğadan alan, ekonomik olarak az sermaye gerektiren, diğer hayvansal üretim dalları arasında düşük girdiye sahip olan ve doğaya en bağımlı hayvancılık koludur. Çünkü bal arılarının yaşamsal gereksinimleri arasında insan eliyle sağlanabilenler, çeşit bakımından son derece sınırlıdır. Ayrıca arıların doğada binlerce bitkiyi dolaşarak kovanlarına getirdikleri nektar, polen ve propolis gibi temel gereksinimlerinin insan 
eliyle toplanıp arılara ve insanlara sunulması olanaksızdır. Bu açıdan bakıldığında arıcılığın başarısını, yani verimliliğini, bir yandan bölgenin yer aldığı iklim kuşağı ve denizden yükseklik gibi coğrafik özelliklerin, bir yandan da sıcaklık, nem, yağış biçimi ve düzeni gibi doğal iklim koşullarının belirlediği söylenebilir (Şengonca, 2004).

Çizelge 1. Dünya arıcılık verileri

Table 1. Beekeeping data in the World

\begin{tabular}{ccccc}
\hline Sıra & Ülke & $\begin{array}{c}\text { Koloni Varlığı } \\
\text { (Adet) }\end{array}$ & $\begin{array}{c}\text { Bal Üretimi } \\
\text { (Ton) }\end{array}$ & $\begin{array}{c}\text { Verim } \\
\text { (Kg/Kovani) }\end{array}$ \\
\hline $\mathbf{1}$ & Hindistan & 13.048 .275 & 67.442 & 5,17 \\
$\mathbf{2}$ & Çin & 9.048 .546 & 446.900 & 49,39 \\
$\mathbf{3}$ & Türkiye & 7.947 .687 & 114.113 & 14.36 \\
$\mathbf{4}$ & İran & 6.601 .394 & 77.567 & 11,75 \\
$\mathbf{5}$ & Etiyopya & 6.018 .223 & 50.000 & 8.31 \\
\hline
\end{tabular}

Gıda ve Tarım Örgütü (FAO) 'nün 2018 yılında yayınlanan ve 2020 yılında güncellenen verilerine göre Türkiye koloni varlığı bakımından dünyada 3 . Sırada yer alırken, bal üretimi bakımından dünyada 2. Sırada yer almaktadır (Çizelge1). FAO verilerine göre bal üretimini en çok gerçekleştirmeyi başaran ülke Çin'dir. Çin 446.900 ton bal üretimi gerçekleştirmiştir (Anonim, 2020).

Arıcılıktan üretilen polen, bal, balmumu, arı sütü, propolis ve arı zehri gibi ürünler insanların sağlıklı ve dengeli beslenmesinin yanı sıra birçok hastalığın tedavisinde de kullanılmaktadır (Şahinler, 2000; Pehlivan ve Gül, 2016). Arılardan elde edilen bu ürünlerin insanlara sağladığı faydanın çok ötesinde önemli bir faydası da bitkilerde tozlanmayı sağlamasıdır (Doğaroğlu, 1999; Kumova ve Korkmaz, 2003). Bu nedenle tarımla uğraşan gelişmiş ülkelere bakıldığında Apis mellifera'yı modern tarım için gerekli ve oldukça önemli bir unsuru olarak kabul etmektedir (Özbek, 2003).

Arı sütü; 5-15 günlük işçi arılarının salgıladığı, yapısının büyük çoğunluğunu (\%60-70) suyun oluşturduğu, kraliçe arının beslenmesinde önemli olan özel besin maddesidir. Arı sütünün yapısında suyun dışında kalan kısmında en düşük oranda \%3 oranında vitamin ve çeşitli amino asitler bulunur. Arılar için önemli olan protein ise arı sütünde \%15 protein, \%6-10 katı formatta yağ, \%12-15 şeker içermektedir.

Propolis önemli bir arı ürünüdür (Kurt ve Şahinler, 2003). Bal arılarının ağaç kabukları, bitki tomurcuk- filiz gibi kısımlarından topladıkları ve salgıladıkları enzimlerle biyokimyasal değişikliğe uğratarak bir miktarda bal mumu ekleyerek oluşturdukları reçinemsi bir maddedir. Propolis hem arılar hem de insanlar arasında birçok amaç için kullanılmaktadır. Arılar ise ürettikleri bu maddeyi kovandaki olumsuz hava koşulları gibi sebeplerle meydana gelen yarık-çatlakları onarmada, kovan içi zararlılardan korunmak için kullanırlar (Krell, 1996; Schmidt, 1997; Greenaway ve ark., 1990; Şahinler, 1999).

Propolisin yapısı ve kimyasal özelliklerinin belirlenmesi için birçok çalışmalar vardır. Bu çalışmalar incelendiğinde propolisin yapısında 300'den fazla kimyasal bileşik belirlenmiştir. Propolisin temel kimyasal yapısını flavonoidler, fenolik asitler, aromatik asitler oluşturmaktadır. Detaylı olarak incelendiğinde analiz sonuçlarında terpenler ve uçucu yağlar, balmumu bulunmaktadır. Propolis antibakteriyel, antiviral, antifungal etkiye sahip reçinemsi bir madde (Şahinler, 1999; Kumova ve ark., 2002) olmakla birlikte birçok yararlı biyolojik aktiviteye sahiptir (Bankova ve ark., 2000).

Bal mumu 12-18 günlük işçi arılar tarafından; yaşam gereksinimleri olan bal ve poleni depolamak, yavru yetiştirmek için ürettikleri maddedir. Sarı veya kahverengi renk tonlarına sahip olan aynı zamanda işçi arıların 4, 5, 6 ve 7. abdominal segmentler de ki mum salgı bezleri tarafından üretilen salgı maddesidir. Bal mumu arıcılıkta tekrar tekrar eritilerek petek yapımında kullanım özelliğine sahip bir üründür (Şahinler, 2000).

Arı zehri acı aynı zamanda renksiz, arıların zehir torbasında oluşum gösteren Sıvı bir kimyasaldır. Apitoksin zehrinin asidik $(\mathrm{pH}$ değeri 4.5 ile 5.5 arasındadır) yapıda olan ve yapısında apamin, mellitin (\%50), Fosfolipaz-A2 (\%12 düzeyinde) enzimlerine sahip bir kimyasal maddedir. Arı zehri aslında eczacılık sektöründe önemlidir çünkü kimyasal yapısına bakıldığında aktif maddeler (\%50 mellitin) içerir. Fiziksel olarak bakıldığında sarımtırak renge sahip olan arı zehri, yapısında yine bir polipeptit olan apamin barındırmaktadır (Kolaylı, 2017).

Yüzyıllar boyunca kullanılan ve doğal ürün olan arı ürünleri, insanlar tarafından birçok amaçla kullanılmıştır. Örneğin beslenme amacıyla, sağlıkta tedavi ve koruma amacıyla yaygın olarak kullanılmıştır (Harissis ve Harissis, 2009). Bunun dışında bu ürünler günümüzde de halen ülke ekonomisine katkı açısından, arıcılık ile geçimini sağlayan insanların gelir kaynağı olması açısından önem taşımaktadır (Bölüktepe ve Yılmaz, 2008).

Uşak ilinde Arıcılığın genel yapısını belirlemeye yönelik yapılan anket çalışmasında, ankete katılan arıcıların yaş ortalaması $53.19 \mathrm{yıl}$, arıcılık deneyimleri 18.47 yıl olduğu, işletmelerin \%17.7'sinin asıl mesleğinin arıcılık olduğu, üreticilerin \%39.2'sinin gezginci arıcılık yaptığı, koloni başına ortalama bal veriminin $12.2 \mathrm{~kg}$ olduğu, arıcıların 
\%30.1'inin ana arıyı 2 yılda 1 değiştirdiği belirlenmiştir(Tabur ve Gül, 2019).

Yapılan bu çalışmada, Ege Bölgesinde yer alan Uşak ilinde 20 Akademisyen, 20 Memur, 20 sıradan tüketici ve 20 öğrenci belirlenerek eğitim, sosyoekonomik ve kültürel yönden farklılık gösteren 80 kişi üzerinde bir anket çalışması gerçekleştirilmiştir. Bu anket çalışmasında amaç, Uşak ilinde arı ürünleri tüketiminin mevcut durumunu belirlemektir.

\section{MATERYAL ve YÖNTEM}

Araştırma materyalini, Uşak ilinde yaşayan farklı eğitim ve ekonomik yapıya sahip tesadüfi olarak seçilmiş 20 Akademisyen, 20 Memur, 20 Öğrenci ve 20 Üniversite dışından seçilmiş kişiler olarak toplam 80 kişi oluşturmuştur.

Seçilen deneklere arı ürünleri ve arı ürünlerinin tüketimi ile ilgili sorular sorularak gruplar arasındaki farklılıklar tespit edilmiştir. Deneklere sorulan soruların ana ana başlıklarını kısaca özetleyecek olursak, tüketicinin, öğrenim durumu, gelir durumu, arı ürünlerinin tüketim miktarı, tüketim sıklığı ve tüketim amacı, arı ürünlerini nereden temin ettiği ve tercih ederken nelere dikkat ettiği gibi konular bulunmaktadır.

Yapılan anket sonunda elde edilen veriler bilgisayarda Anket Değerlendirme Analiz (ADA) paket programı ile analiz edilmiştir.

\section{BULGULAR ve TARTIŞMA}

\section{Tüketiciler ile ilgili özel bilgiler}

Yapılan Anket çalışmasına katılan 80 kişinin \%25 Akademisyen, \%25 Öğrenci, \%25 Memur, \%25 diğer meslek grupları Tüketicilerden oluşmaktadır (Şekil 1).

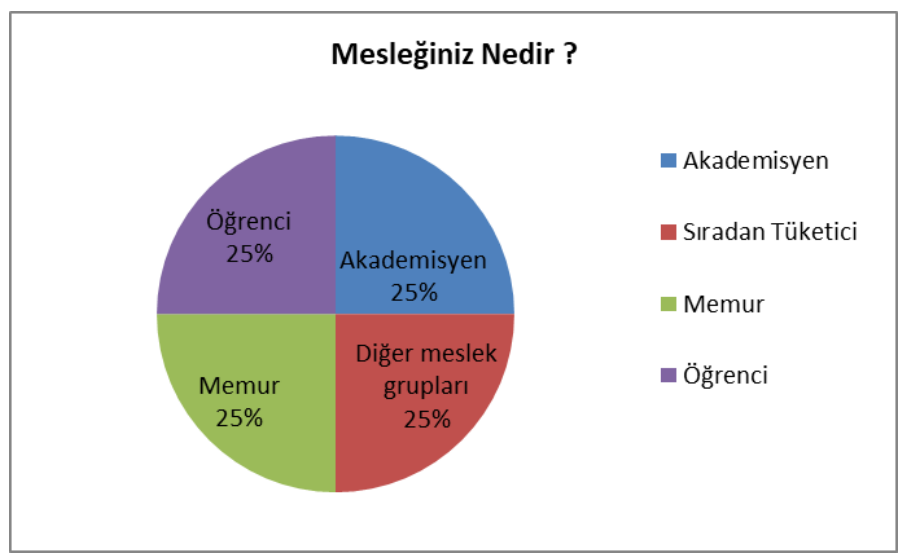

Şekil 1. Tüketicilerin meslek gurupları

Figure 1. Consumers' occupational groups
Yapılan inceleme ve istatistikî sonuçlara göre ankete katılan 80 kişinin eğitim durumlarına bakıldığında, Katılımcıların eğitim seviyelerinin yüksek olduğu, \%50 oranında üniversite mezunu olduğu, \%16 lise, \%8 ortaokul, \%10 ilkokul mezunu olduğu belirlenmiştir. Katılımcıların okuryazar olanlarının seviyesininde \%16 gibi yüksek bir oranda olduğu tespit edilmiştir (Şekil 2).

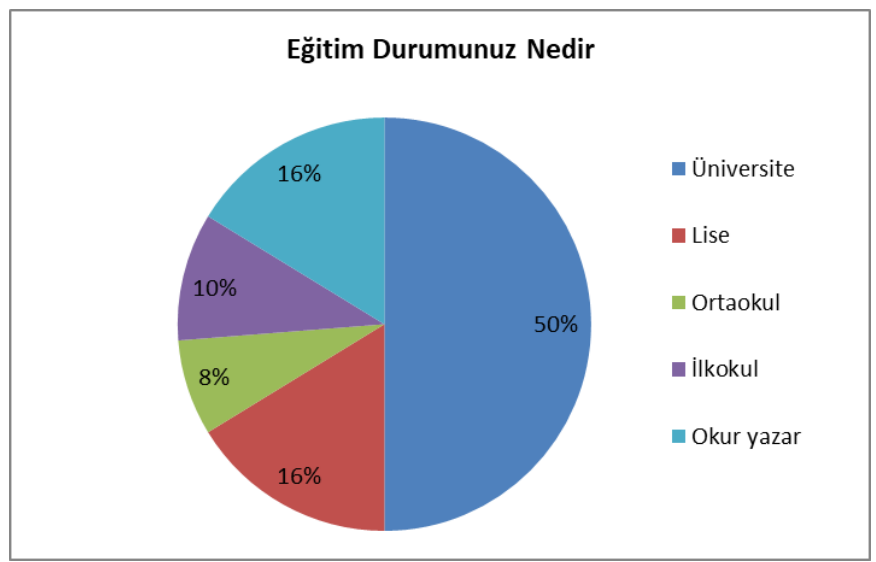

Şekil 2. Tüketicilerin eğitim durumu

Figure 2. Education status of consumers

Sayılı'nın (2013) yılında gerçekleştirdiği araştırmada ise Tokat ilinde ankete katılan tüketicilerin eğitim düzeyinin Görüşülen tüketicilerin eğitim durumları incelendiğinde; \%8.09'unun da doktora mezunu olduğu halde \%7.72'sinin yüksek lisans, \%34.92'sinin üniversite, $\% 9.56$ 'sının ilkokul ve \%6.62'sinin ortaokul, ayrıca \%33.09'unun lise mezunu oldukları belirlenmiştir. Niyaz ve Demirbaş'ın (2017) yaptıkları araştırmada ise Çanakkale ilinde 175 tüketici ile gerçekleştirdikleri çalışmada ise; \%2.3'ü yalnızca okur-yazar iken \% 24'ü ilköğretim, \% 35.4'ü lise, \%36.6'sı üniversite, \% 1.7'sinin de yüksek lisans mezunu olduğunu bildirmişler. Başka bir çalışmada ise sadece üniversite öğrencilerinin katıldığı, öğrencilerin arı ürünlerini tanıması üzerine gerçekleştirilmiş. Bu çalışmada yer alan öğrencilerin eğitim durumu ise \%65.7'sinin lisans eğitim seviyesine sahip öğrencilerden geri kalan kısmın ise önlisans eğitimine sahip olduğunu bildirilmiştir (Saral ve Yavuz, 2020).

Katılımcıların gelir düzeylerine bakıldığında ise Anket katılımcılarının ekonomik durumları 3000 ve üzeri olanların oranı $\% 50$ dir. Bu oranda akademisyen ve memur katılımcılar etki değeri yüksektir. 2000-3000 TL gelir düzeyi \%16, 1500-2000 arası \%8, 1000-1500 TL arası \%10 dur. Genel olarak öğrenci katılımcı gruplarının etkisiyle 500-1000 TL gelire sahip olan katılımcıların \%16 gibi bir orana tekabül etmesine sebep olduğu gözlemlenmiştir (Şekil 3). 


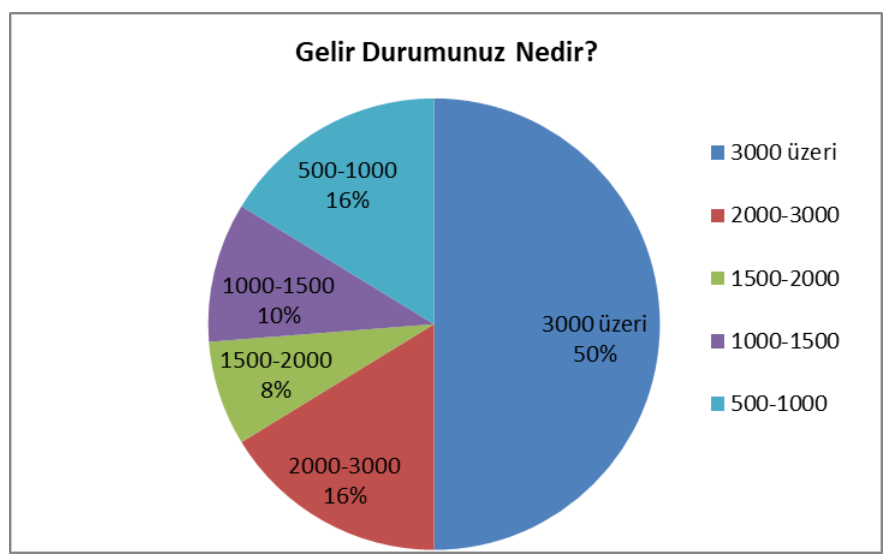

Şekil 3. Tüketicilerin gelir durumu

Figure 3. Consumers' income status

Şahinler ve ark. (2004) Hatay ilinde arıcılık ürünlerinin tüketimlerinin belirlemesi üzerine gerçekleştirdiği çalışmada ise; tüketicilerin gelir durumu değerlendirilmiş. Sonuçlara bakıldığında ise tüm katılımcıların \%8.7'si 200 TL den az, \%17'si 201-400 TL, \%20.4'ü 401-600 TL, \%28.2'si 601-800 TL ve \% 24.3'ü ise $800 \mathrm{TL}$ ve üzeri olarak belirlemişlerdir. Araştırmada ise gelir düzeyi ile arı ürünlerinin tüketim durumunu karşılaştırdıklarında ise arı ürünleri tüketim durumu ile gelir düzeyi arasında önemli bir ilişkinin bulunmadığını yani, farklı gelir düzeyine sahip olsalar da her insanın arı ürünlerine sahip olabildiğini belirtmişlerdir. Bölüktepe ve Yılmaz' ın (2008) arı ürünlerinin bilinirliği ve satın alınma sıklığı üzerine gerçekleştirdiği araştırmada katılımcıların gelir düzeyinin katılımcıların arasında oranı \%10.3'nün 500 TL ve daha az, \%24.7'sinin 501-800 TL, \%30.7'sinin 801-1000 TL, \%22.9'unun 1001-2000 TL, \%11.3'nün 2000 TL'den daha fazla olan gelir grubunda yer aldığı sonucuna ulaşmışlardır. Tüketicilerin gelir durumuna bakıldığında \%78.3'lük kesiminin aylık gelir düzeylerinin 501-2000 TL arasında olduğu bildirilmiştir. Yaptıkları çalışmada ise amaçları arı ürünlerinin bilinirliğinin gelir düzeyi ile bağlantılı olup olmadığını saptamak olmuştur. Sonuçlara göre bal, polen, arı sütü, propolis, bal mumunun bilinirliğinin gelir düzeyi ile orantılı olduğu sonucuna ulaşmışlardır.

Arı ürünü olan arı sütü, polen, bal, propolisin tüketiciler arasında bilinirliğini belirlemek amacı ile 'Bildiğiniz arı ürünleri nelerdir?' sorusu yöneltilmiştir.

Tüketicilerin verdikleri cevaplara göre arı ürünlerinin (bal, polen, propolis, arı sütü arasından) hepsini bilen kişi sayısı \%69 oranındadır. Geriye kalan \%31'lik kısım ise sadece balı bilmektedir (Şekil 4).

Arı ürünlerini ne sıklıkla tükettiği sorulan 80 kişiden ise günlük arı ürünü kullanımı $\% 42$, haftalık \%39 ve aylık ise \%19 oranında olduğu belirlenmiş (Şekil 5).

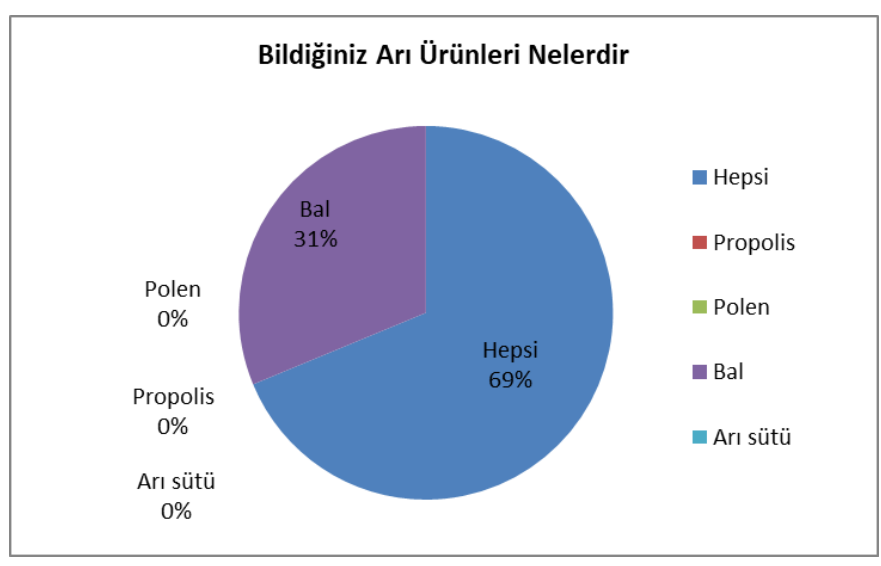

Şekil 4. Tüketicilerin bildiği arı ürünleri

Figure 4. Bee products known to consumers

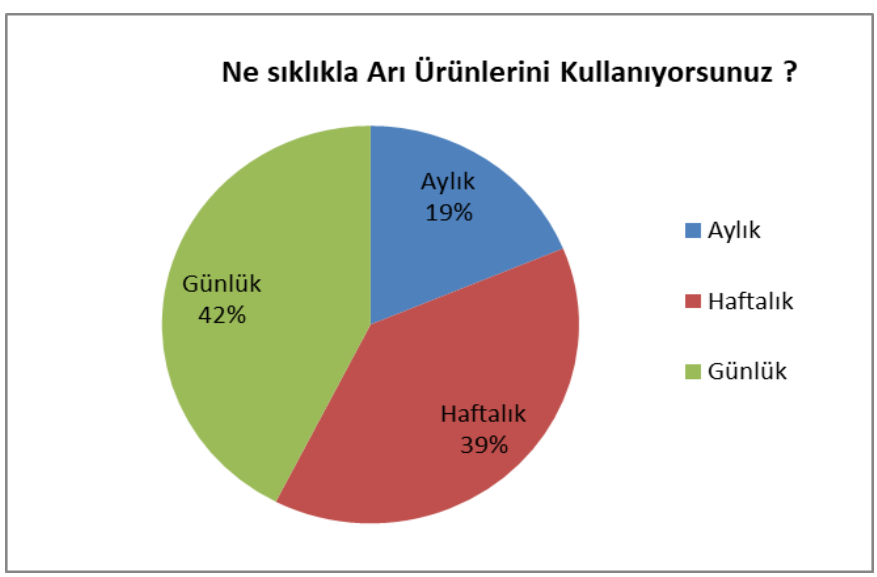

Şekil 5. Tüketicilerin arı ürünleri kullanım sıklığı

Figure 5. Frequency of consumers using bee products

Çanakkale ilinde gerçekleştirilen bir araştırmaya göre; tüketicilerin \% 12'sinin haftada bir \% 45.1'nin ayda bir, \% 16 'sının iki ayda bir, \% 14.9'u altı ayda bir, \% 11.4'ü yılda bir ve \% 0.6'sı daha nadir bal satın aldığı sonucuna ulaşmışladır. Ürünlerinin tüketici tarafından kullanılma sıklığına bakıldığında ise bal tüketme sıklığı \% 33.8 her zaman, \% 21.1 genellikle, \% 17.7 sıklıkla, \% 7.4 bazen, \% 9.1 nadiren, \% 10.9'u çok nadiren bu ürünü tükettiğini belirtmişlerdir. Diğer arı ürünlerini ise ankete katılan tüketicilerin \% 98.9' u arı zehrini, \% 99.4'ü bal mumunu \% 89.1'i propolisi, \% 82.9'u poleni, \% 95.4'ünün arı sütünü hiç tüketmediği sonucuna ulaşmışlardır (Niyaz ve Demirbaş, 2017).

Tüketicilere arı ürünlerini nerden temin ettikleri sorulduğunda ise \%63'nün marketlerden, \%31'nin arıcılardan almakta olduğu tespit edilmiştir. Günümüzde sıkça kullanılan internet alışverişine rağmen katılımcıların internetten arı ürünleri temin edilmediği belirlenmiştir. Ayrıca $\% 6$ oranında katılımcı arı ürünü teminini kendisi karşılamaktadır (Şekil 6). 


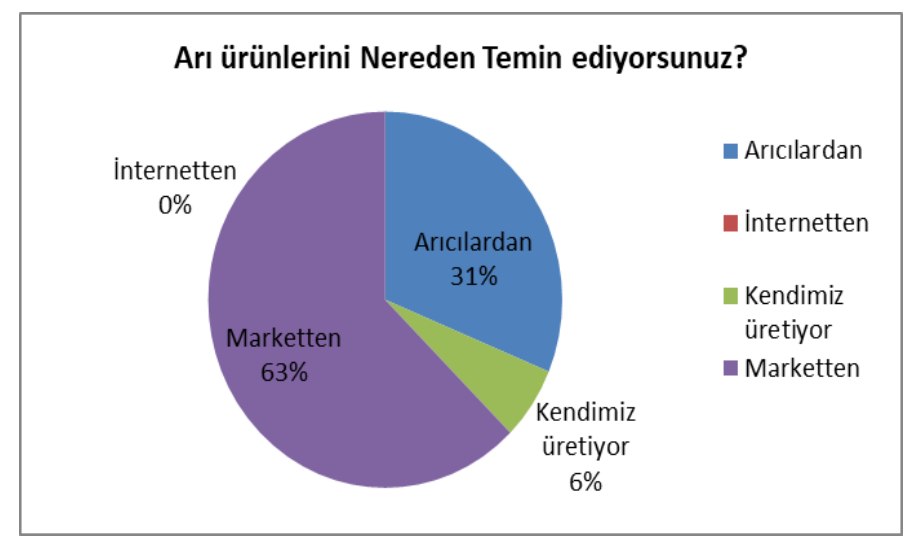

Şekil 6. Tüketicilerin arı ürünlerini temin ettikleri yerler Figure 6. Where consumers get their bee products from

Türkiye'nin bazı illerinde arı ürünlerinin farkındalıkları ve tüketici alışkanlıkları üzerine gerçekleştirilen çalışmaya göre; \%41 tüketici ballarını market ve pazardan alırken, sanal olarak gerçekleştirilen internet ayrıca televizyondan satışa sunulan arı ürününün satın alınması \%7.8 oranında olduğunu belirlemişlerdir (Tunca ve ark., 2015).

Tüketicilerin arı ürünleri satın alırken dikkat ettiği kriterlere bakıldığında ise; Arı ürünlerini alırken $\% 74$ oranında bir çoğunluk marka, fiyat, ambalaj gibi tüm kriterlere dikkat ettiğini belirtmişlerdir. \%14'ü markaya, \%5'i ambalaja, \%'i sadece fiyatına bakmakta olduğunu fakat $\% 6$ oranında katılımcı herhangi bir kritere dikkat etmediğini belirtmiştir (Şekil 7).

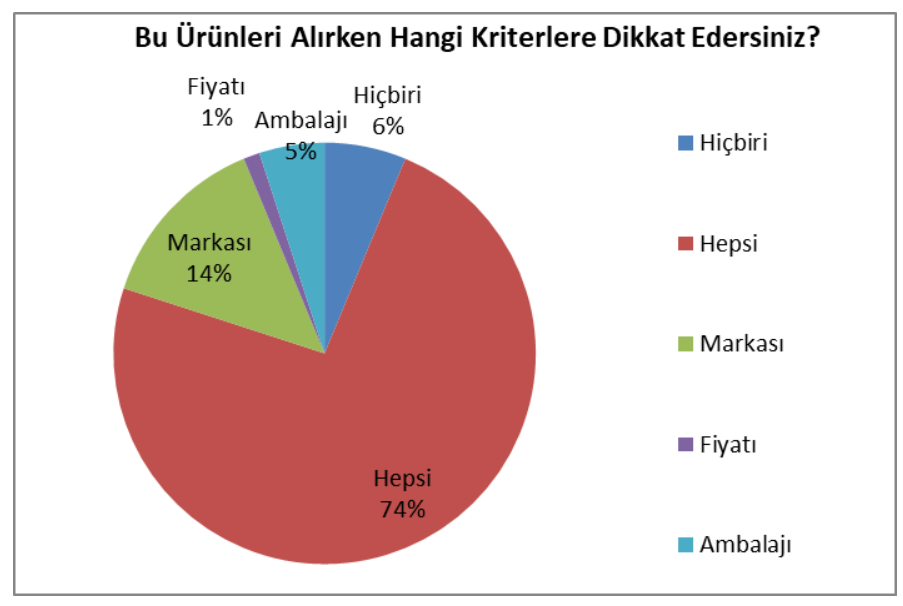

Şekil 7. Tüketicilerin arı ürünleri satın alırken kriterleri

Figure 7.Consumers' criteria when purchasing bee products

Tüketicilerin arı ürünlerinde marka tercihi üzerine yapılan başka bir çalışama da ise ankete katılanların \%65.5'nin markaya önem verdiği sonucuna ulaşmışlardır (Merda, 2018). Şahinler ve ark. (2004)'te yaptıkları çalışmada ise arı ürünü olan balı satın alırken kriterlerinin ne olduğu sorulmuştur. Tüketicilerin verdiği cevaplara bakıldığında ise düşük gelirli olanlar fiyat, yüksek gelirli olanlar ise kalite ve nektar oranına dikkat ettiklerini bildirmişlerdir.

Tunca ve ark. (2015) yaptıkları çalışmada ise 1112 kişinin katıldığı anket çalışmasında tüketicilerin bal alırken dikkat ettiği kriterlerin başında marka (\%52.7) olduğunu belirlemişlerdir. Yapılan çalışmada tüketicilere neden markaya dikkat etme sebepleri sorulduğunda ise ürünün markasının olmasını \%74,5'i kalitesini gösterdiğini ve onlar için güven taşıdığını olarak ifade etmişlerdir.

Karahan ve Özbakır (2020) yılında arıcılara bal alırken insanların dikkat ettiği kriterler nelerdir diye sormuşlar. Ankete katılan arıcıların verdiği cevaba göre ise tüketicilerin $\% 57.8^{\prime} i$ kalite, $\% 38.5^{\prime} i$ fiyata dikkat ettiklerini bildirmiştir.

Arı ürünlerini kullanan katılımcılara hangi arı ürününü daha çok kullandığı sorulduğunda ise Anket katılımcıları hangi arı ürününü kullanıyorsunuz sorusuna $\% 60$ sadece bal kullandıklarını ve diğer arı ürünlerini kullanmadıklarını belirtmişler (Şekil 8).

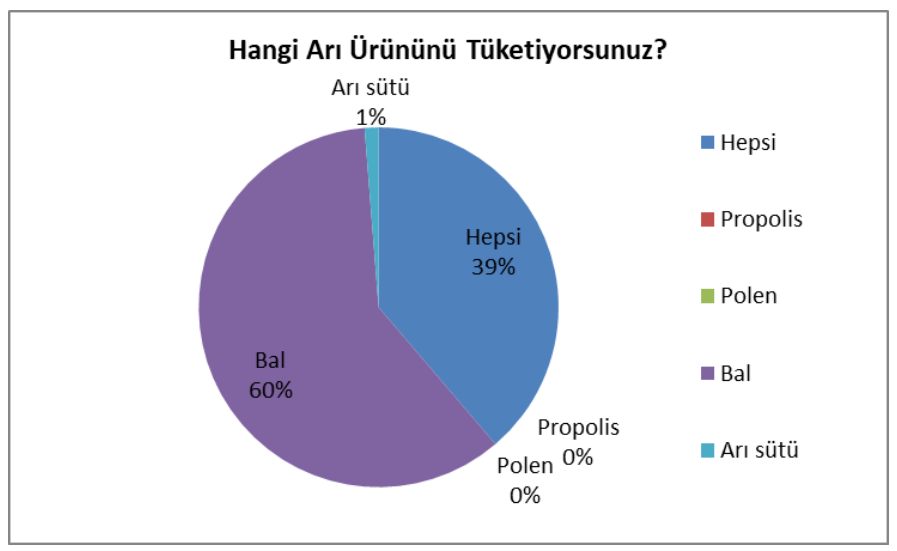

Şekil 8. Tüketicilerin arı ürünleri tercihi

Figure 8.Consumers' bee product preferences (\%)

Sadece propolis ve polen kullanan olmadığı belirlenmiş ve Tüm arı ürünlerinin tamamını kullananların oranının ise \%39 dur. Eğitim seviyesinin ve ekonomik düzeyin artması ile arı ürünü kullanım çeşitliliği artmakta olduğu belirlenmiştir. Melda'nın (2018) Tüketicilerin marka algısı üzerine gerçekleştirdiği çalışmada ise ankete katılanların \%92.4 sinin arı ürünü olarak balı tercih ettiğini belirtmiştir. Arı sütü, polen, propolis arasından ise en yüksek değeri arı sütü (\%6.5) izlemektedir. Yapılan başka bir araştırmaya göre de bal dışındaki diğer arı ürünlerinin tüketenlerin (\%31.5) tercihi polen olduğu bildirilmiştir (Karahan ve Özbakır, 2020).

Arı ürünlerinin tüketilme sebebini araştırdığımız soruda ise en çok \%38 oranla vücut direncinin artması için cevabı işaretlenmiştir. Ankete katılanların \%32'lik kısmı beslenme, \%26'lık kısmı hastalıklara karşı korunmak 
amaçlı ve \%4 gibi az bir oran ise tadından dolayı arı ürünü tükettiğini belirtmiştir. Belirlenen bu oranlar arı ürünlerinin genel özellikleri hakkında bilgi sahibi olduklarının bir göstergesidir (Şekil 9).

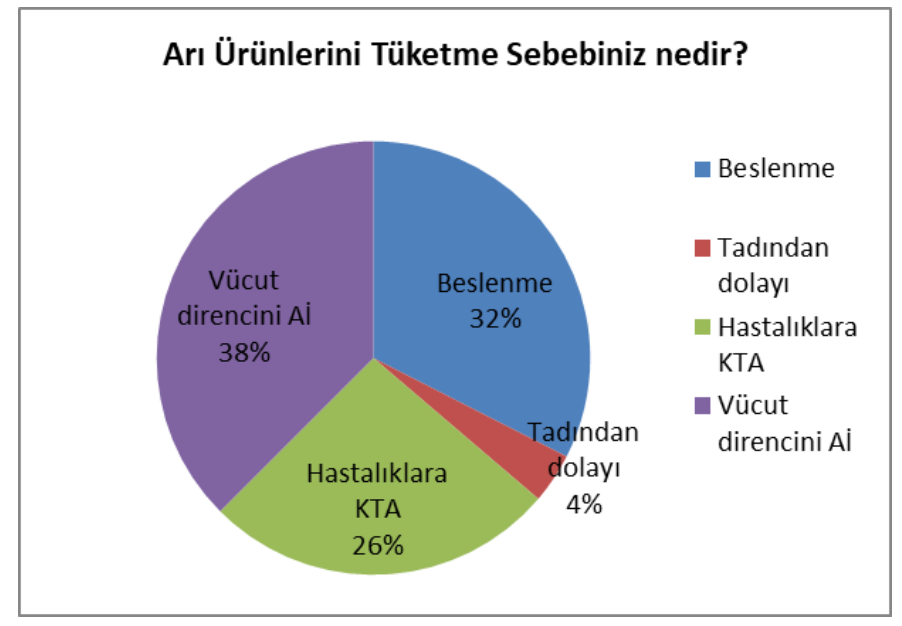

Şekil 9.Tüketicilerin arı ürünleri kullanma nedenleri

Figure 9. Reasons for consumers to use bee products

Katılımcılar arasında Arı ürünleri tüketiminin bilinirliği ve kullanımının oldukça fazla olduğu belirlenmiştir. Ankete katılan 80 kişiye arı ürünleri ile ilgili gelişmeleri takip edip etmediği sorulmuş; verilen cevaplara bakıldığında ise Şekil 10 da görüldüğü gibi Arı ürünleri ile ilgili gelişmelerin \%46 oranında takip edilmediği, takip edenlerin ise \%22'lik kısmı Tarım İl ve İlçe Müdürlüğü, $\% 16^{\prime}$ lık kısmı kitap ve \%16'lık kısmının dergilerden takip edildiği belirlenmiştir.

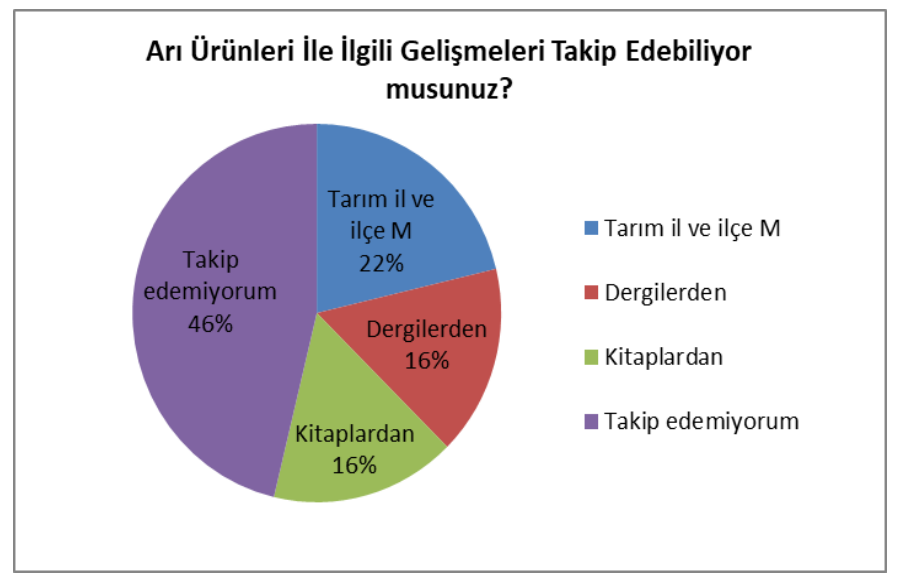

Şekil 10. Tüketicilerin arı ürünleri ile ilgili gelişmeleri takibi

Figure 10. Following the developments of the consumers regarding bee products

Ayrıca yapılan bu çalışmada katılımcılar arı ürünlerinin tanıtımının \%87 gibi yüksek bir oranla yeterli bulmadığı, sadece \%13 katılımcı tanıtımın yeterli olduğunu belirtmişlerdir (Şekil 11). Anket katılımcılarının \%67.5 oranı çevrelerinde bildikleri arı ürünleri üreticisi olduğunu belirtmiştir.

\section{Arı Ürünlerinin Tanıtılmasını Yeterli Buluyor musunuz?}

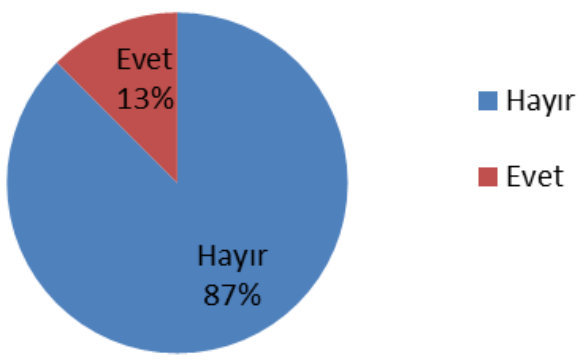

Şekil 11.Tüketiciler tarafından arı ürünleri tanıtımları Figure 11. Qualification assessment of bee products promotion by consumers

\section{SONUÇ ve ÖNERILER}

Arı ürünlerinin bilinirliği ve kullanım oranı son yıllarda artış göstermiştir. Arı ürünlerinin kullanımının artması hem ülke ekonomisi açısından hem de insan sağlığına olan faydaları açısından oldukça önem taşımaktadır. Arı ürünlerinin kullanımının artması için tüketici özelliklerinin ve tercihlerinin bilinmesi büyük önem taşır. $\mathrm{Bu}$ sebepledir ki arıcılık ve arı ürünleri ile yapılan çalışmalar giderek önem taşımaktadır.

Araştırmaya göre arı ürünleri tüketicilerin bazı özellikleri incelendiğinde büyük çoğunluğunun eğitim düzeyinin üniversite olduğu gözlenmiştir. Toplumun birçok kesimine göre eğitim düzeyi oldukça yüksektir. Arı ürünleri olan propolis, bal, bal mumu, polen arı sütü, arı zehri arasından en çok bal kullandıkları sonucuna ulaşılmıştır. Birçoğunun ise bütün arı ürünlerinin yani bal, polen, propolis, arı sütünü tükettikleri sonucuna ulaşılmıştır.

Yapılan anket çalışmasında katılımcıların büyük oranda arı yetiştiriciliği ile uğraşan kişilerle iletişimi olduğu böylelikle arı ürünleri ile ilgili konulara yabancı olmadıkları belirlenmiştir. Ankete katılan tüketicilerin birçoğunun arı ürünlerini tüketmekte olduğu belirlenmiştir. Gelir düzeyine bağlı olarak arı ürünlerinin kullanım çeşitliliğinin arttığı da tespit edilmiştir. Tüketicilerin arı ürünleri satın alırken tercih kriterleri arasında büyük çoğunluğunun marka kriterini dikkate aldığını ortaya koymaktadır.

Artan gelir durumu ve eğitim seviyelerinin arı ürünleri hakkında bilgiyi, bunun yanısıra arı ürünleri kullanım düzeyini de arttırdığı gözlenmiştir. Tüketiciler arasında yer alan öğrencilerin bilgi düzeyleri yeterli olsa da 
ekonomik koşullardan kaynaklı arı ürünleri kullanım oranının düşük olduğu belirlenmiştir. Bu çalışma ile arı ürünleri ile ilgili tanıtımın yetersiz olduğu ve bu konuda gerekli kurumların daha efektif bir tanıtım çalışması yapması gerektiği belirlenmiştir. Uşak ili arıcılık bakımından önemli bir bitki florasına sahiptir. Bu nedenle bu bölgede arıcılığı geliştirmeli ve arıcılık ile elde edilen bu muhteşem ürünlerin tanıtım için çalışmaları yapılmalıdır.

\section{ÖZET}

Amaç: Ege Bölgesinde yer alan Uşak ilinde arı ürünlerinin tüketici özelliklerinin, alışkanlıklarının ve farkındalıklarının belirlenmesi, arı ürünlerinin bilinirliği değerlendirmektir.

Yöntem ve Bulgular: Çalışmanın materyalini Uşak ilinden rastgele seçilen 20 Akademisyen, 20 Memur, 20 Üniversite dışı seçilmiş kişiler ve 20 öğrenci olmak üzeri 80 kişiye yapılmış olan anket çalışması sonucunda elde edilen orijinal veriler oluşturmuştur. Çalışmaya katılan tüketicilerin $\% 50$ 'sinin eğitim durumunun üniversite olduğu; \%50'sinin 3000 TL ve üzeri gelire sahip olduğu, \%99'nun arı ürünlerini tükettiği belirlenmiştir. Arı ürünleri arasında tüketiciler tarafından en çok tüketilen arı ürünün bal olduğu belirlenmiştir. Yine tüketicilerin \%74 'ü arı ürünleri satın alırken ambalajlı, markalı ürünler tercih edilmektedir. Sonuç olarak arı ürünlerinin bilinirliğinin eğitim düzeyine ve artan gelir düzeyine göre kullanımın arttığı ifade edilmiştir.

Genel Yorum: Ülkemiz zengin bitki florası ve bitkisel ürün çeşitliği ile arıcıların herhangi bir yere ve yöreye bağlı kalmayıp yıl içerisinde birkaç yer değiştirerek farklı besin madde içeriğine sahip çeşitli bal (salgı ve çiçek balı) ve arıcılık ürünleri elde etmesine olanak sağlamaktadır. Arıcılık çalışmaları sonucunda, bal, ana arı ve oğul üretiminin yanı sıra bal mumu, arı sütü, polen, arı zehri ve propolis gibi birçok ürün elde edilmektedir. Çalışma sonucunda katılımcıların çoğunluğunun arı ürünleri hakkında bilgi sahibi olup tüketmekte olduğu gözlemlenmiştir. Ancak arı ürünleri ile ilgili tanıtımın yetersiz olduğu ve bu konuda gerekli kurumların daha efektif bir tanıtım çalışması yapması gerektiği belirlenmiştir.

Çalışmanın Önemi ve Etkisi: Yapılan çalışma ile Ege Bölgesinde bulun Uşak ilinde tüketicilerin arı ürünlerine olan eğilimleri belirlenmiştir. Aynı zamanda tüketim tercihleri, arı ürünlerini satın alma yerleri, arı ürünleri satışındaki eksiklikler belirlenerek arıcılık ile uğraşanlara ve yapılacak diğer çalışmalara kaynak teşkil edeceği düşünülmektedir.
Anahtar Kelimeler: Uşak ili, arı ürünleri, anket, tüketim

\section{ÇIKAR ÇATIŞMA BEYANI}

Yazarlar çalışma konusunda çıkar çatışmasının olmadığını beyan eder.

\section{ARAŞTIRMACILARIN KATKI ORANI BEYANI}

Yazarlar çalışmaya eşit oranda katkı sağlamış olduklarını beyan eder.

\section{KAYNAKLAR}

Anonim (2020) Tarım Orman Bakanlığı Arıcılık Araştırma Enstitüsü Müdürlüğü, Arıcılık İstatistikleri, https://arastirma.tarimorman.gov.tr/aricilik/Belgeler /istatistik/2018\%20YILI\%20D\%C3\%9CNYA\%20ARICILI K\%2OVER\%C4\%BOLER\%C4\%B0\%2002.03.2020.pdf (Erişim Tarihi:04.06.2020).

Bankova VS, Castro SL, Marcucci MC (2000) Propolis: recent advances in chemistry and plant origin. Apidologie 31: 3-15.

Bölüktepe $F E$, Yılmaz S (2008) Arı ürünlerinin bilinirliği ve satın alınma sıklığı. Uludağ Arıcılık Dergisi 8(2): 53-62.

Doğaroğlu M (1999) Modern Arıcılık Teknikleri. Anadolu Matbaa ve Ambalaj San. Tic. Ltd. Şti. İstanbul. 296 sayfa.

Greenaway W, Scaysbrook T, Whatley FR (1990) The composition and plant origins of propolis. A Report of Work at Oxford. Bee World 71(3): 107-118

Harissis HV, Harissis AV (2009) Apiculture in the Prehistoric Aegean: Minoan and Mycenaean symbols revisited. British Archaeological Reports, John and Erica Hedges, Oxford. 95 pp.

Karahan Ş, Özbakır GÖ (2020) Güneydoğu Anadolu'da Arıcılık Faaliyetlerinin ve Bal Tüketim Alışkanlıklarının Belirlenmesi. Türk Tarım ve Doğa Bilimleri Dergisi 7(4): 1148-1158.

Kolaylı S (2017) Bal arısı zehrinin karakterizasyonunda SDS-page elektroforez kullanılabilirliğinin araştırılması. Uludağ Arıcılık Dergisi 16(2): 49-56.

Krell R (1996) Value-Added products from beekeeping. FAO Agricultural Services Bulletin No. 124. Food and Agriculture Organization of the United Nations, Rome.

Kumova U, Korkmaz A (2003) Bal arısı (Apis mellifera L.) kolonilerinde nektar akımı öncesi polen üretiminin koloni populasyonuna olan etkilerinin araştırılması. Mellifera 3(5): 23-29.

Kumova U, Korkmaz A, Avcı BC, Ceyran G (2002) Önemli bir arı ürünü propolis. Uludag Arı Dergisi 2: 10-24. 
Kurt Ş, Şahinler N (2003) Propolis eksraktının bitki patojeni funguslara karşı antifungal aktivitesi. Uludağ Arı Dergisi 3: 35-37.

Niyaz ÖC, Demirbaş N (2017) Arı ürünleri tüketicilerinin genel özellikleri ve tüketim tercihleri: Çanakkale ili örneği. Tarım Ekonomisi Dergisi 23(2): 255-262.

Özbek H (2003) Türkiye'de arılar ve tozlaşma sorunu. Uludağ Arıcilık Dergisi, 3(3): 41-44.

Pehlivan T, Gül, A. (2016) Türkiye'de Üretilen Keçiboynuzu, Kekik ve Sütleğen Ballarının Kimyasal Özellkleri. Mustafa Kemal Üniversitesi Ziraat Fakültesi Dergisi 21(1): 48-56.

Sayılı M (2013) Tokat ilinde tüketicilerin arı ürünleri tüketim durumları ve alışkanlıkları. Uludağ Arıcılık Dergisi 13: 16-22.

Schmidt JO (1997) Bee products, chemical composition and application. In: Bee Product: Properties, Applications and Apitherapy, Mizrahi A, Lensky Y. (Eds.), Springer US, p. 15-26.

Saral Ö, Yavuz AY (2020) Rize ili üniversite öğrencilerinin arı ürünlerini tanıma durumu ve kullanım alışkanlıklarının belirlenmesi. Uludağ Arıcılık Dergisi 20(2): 172-180.
Şahinler N, Şahinler S, Gül A, Görgülü Ö (2004) Arı Ürünleri Tüketici Özelliklerinin Belirlenmesi Üzerine Bir Çalışma. IV Ulusal Zootekni Bilim Kongresi cilt 2. Poster bildiriler kitapçığı, 1-3 Eylül, Isparta, s.53-57

Şahinler N (2000) Arı ürünleri ve insan sağlığı açısından önemi. MKÜ Ziraat Fakültesi Dergisi 5(1-2): 139-148.

Şahinler N (1999) Propolisin bileşimi ve kullanım olanakları. MKÜ Ziraat Fakültesi Dergisi 4(1-2): 167180.

Şengonca M (2004) Arı Genetiği ve Islahı. Ege Üni. Ziraat Fak. Yay, 559 sayfa.

Tabur Z, Gül, A (2019). Uşak ilinde arı yetiştiricilerinin sosyo-ekonımik durumu ve arıcılığın teknik özelliklerinin belirlenmesi. Mustafa Kemal Üniversitesi Tarım Bilimleri Dergisi 24(2): 146-152.

Tunca Ri, Taşkın A, Karadavut U (2015) Determination of bee products consumption habits and awareness level in some provinces in Turkey. Turkish Journal of Agriculture-Food Science and Technology 3(7): 556561. 